\title{
Profiling the occurrence of biogenic amines in different types of tuna samples using an improved analytical approach
}

\author{
Joanna K.G. Pataca ${ }^{\text {a }}$, Priscilla Porto-Figueira ${ }^{\mathrm{a}}$, Jorge A.M. Pereira ${ }^{\mathrm{a}}$, Helena Caldeira ${ }^{\mathrm{a}, \mathrm{b}}$, José \\ S. Câmara ${ }^{\mathrm{a}, \mathrm{c}, *}$ \\ ${ }^{a}$ CQM - Centro de Química da Madeira, Universidade da Madeira, Campus da Penteada, 9000-105, Funchal, Portugal \\ ${ }^{\mathrm{b}}$ Faculdade de Ciências da Vida, Universidade da Madeira, Campus Universitário da Penteada, 9000-105, Funchal, Portugal \\ ${ }^{\mathrm{c}}$ Faculdade Das Ciências Exatas e Engenharia, Universidade da Madeira, Campus Universitário da Penteada, 9000-105, Funchal, Portugal
}

\section{A R T I C L E I N F O}

\section{Keywords:}

Biogenic amines (BAs)

Tuna samples

USA $\mu$ ET

DnsCl

UHPLC-FLD

Food safety

\begin{abstract}
A B S T R A C T
Food deterioration caused by microbial agents often involve the formation of biogenic amines (BAs), which can have harmful effects on human health. In this study a set of BAs - tryptamine, cadaverine, putrescine, spermine, histamine, tyramine, and spermidine, were simultaneously analysed to monitor their occurrence in different types of tuna samples. An improved extraction approach involving ultrasound-assisted microextraction (USA $\mu$ ET) followed by derivatization with dansyl chloride ( $\mathrm{DnsCl}$ ) and analysis by ultrahigh performance liquid chromatography (UHPLC) with fluorescence detection was validated for BAs quantification. The performance of the USA $\mu$ ET/UHPLC-FLD was assessed by studying the limits of detection (LOD) and quantification (LOQ), linear dynamic range (LDR), precision (intra and inter-day) and matrix effect (ME). Good linearity $\left(\mathrm{r}^{2}>0.98\right)$, LODs (from 0.98 to $8.57 \mathrm{mg} \mathrm{kg}^{-1}$ ) and LOQs (3.20-25.6 $\mathrm{mg} \mathrm{kg}^{-1}$ ) were achieved for all BAs analysed. Recoveries ranged from $76 \%$ to $106 \%$, with relative standard deviations (RSD) lower than $5.0 \%$. ME was determined from 7.52 to $50 \%$ and the intra and inter-day precisions ranged from 4.7 to $11.6 \%$ and $5.5-14.2 \%$, respectively. BAs levels varied significantly from $4.09 \pm 0.8 \mathrm{mg} \mathrm{kg}^{-1}$ of putrescine in olive oil canned samples to $577.9 \pm 5.9 \mathrm{mg}$ $\mathrm{kg}^{-1}$ of cadaverine in natural canned samples. Tryptamine and tyramine were not detected in any of the samples analysed, while spermine and spermidine were found in $85.7 \%$ of the assayed tuna samples. Cadaverine was the most dominant BA with concentrations ranging from $54.3 \pm 2.5 \mathrm{mg} \mathrm{kg}^{-1}$, in olive oil canned tuna, to $577.9 \pm$ $5.9 \mathrm{mg} \mathrm{kg}^{-1}$, in natural canned samples, whereas putrescine had the lowest concentration (average $6.9 \pm 2.5 \mathrm{mg}$ $\mathrm{kg}^{-1}$ ). The validated methodology revealed important improvements in terms of simplification of the experimental layout, expressed in the low sample and reagent amounts, in addition to less time-consuming and labourintensive requirements that did not compromise the analytical performance.
\end{abstract}

\section{Introduction}

Fish is a food with high nutritional value and easy to digest, making it essential in human diet. However, it is also highly perishable, and its quality can drop very quickly soon after its capture, particularly when improper handling and poor hygiene conditions are used. In such cases, the appearance of undesirable odours and flavours as a result of enzymatic and bacterial reactions may involve the formation of harmful compounds, as biogenic amines (BAs) (Mercogliano \& Santonicola, 2019). These basic, non-volatile, low molecular weight organic compounds containing nitrogen atoms (Mercogliano \& Santonicola, 2019) can be classified into monoamines, diamines, and polyamines according to the number of amine groups or in aliphatic, aromatic, and heterocyclic considering their chemical structure (Fig. 1A). Although some fishes from the Scombridae family have endogenous high levels of free histidine, the precursor of histamine (Hist), often BAs occurrence in fresh fish is very low as these compounds result essentially from bacteria or yeast proliferation (Đorđević, Buchtová, \& Borkovcová, 2016). As food deterioration progresses, bacteria and yeast activities increase boost the levels of different BAs, Hist, tyramine (Tyrm), tryptamine (Try), putrescine (Put) and cadaverine (Cad), which result from the decarboxylation of histidine, tyrosine, tryptophan ornithine and lysine, respectively (Santos et al., 2019). Ultimately, high levels of different BAs determine the loss of organoleptic characteristics, making the fish

\footnotetext{
* Corresponding author. CQM - Centro de Química da Madeira, Universidade da Madeira, Campus da Penteada, 9000-105, Funchal, Portugal.

E-mail address: jsc@staff.uma.pt (J.S. Câmara).
} 


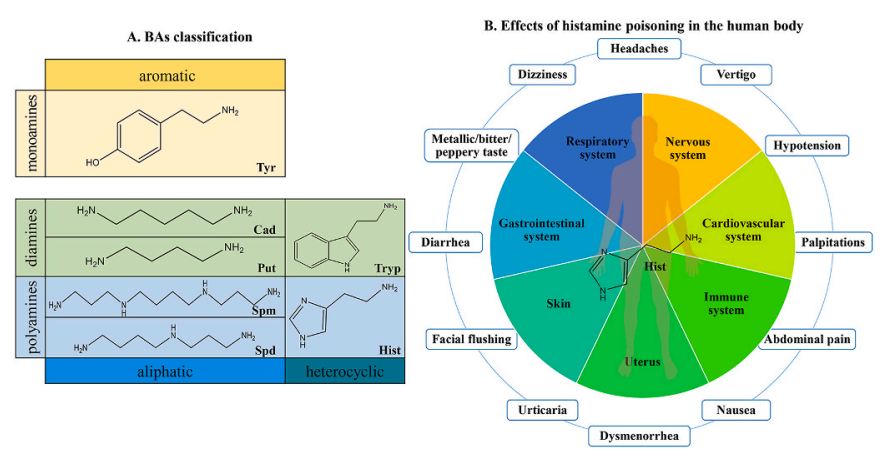

Fig. 1. Classification of selected BAs according to the number of amine groups and structure (A) and toxic health effects and symptoms related with Hist poisoning (adapted from Feng et al., 2016) (B). Legend: BAs - Biogenic Amines; Try - Tryptamine; Put - Putrescine; Cad - Cadaverine; Spm - Spermine; Hist Histamine; Tyrm - Tyramine; Spd - Spermidine.

unsafe for human consumption and unsuitable for commercialization. Among BAs, Hist is the most harmful causing a myriad of toxic effects involving diverse biological functions and systems, including the cardiopulmonary, nervous, digestive, and immune systems (Mercogliano \& Santonicola, 2019) (Fig. 1B). In addition, it acts synergistically with other amines for fish poisoning and decomposition (Mercogliano \& Santonicola, 2019).

Hist poisoning represents therefore, an obvious problem of public health and hence the eventual presence of high levels of BAs has been studied in various foods, including fish (Santos et al., 2019). Moreover, specific legislation establishes legal limits for BAs presence in fish and fishery products to protect consumers from spoiled fish intake (COMMISSION REGULATION (EC), 2005). According to the Food and Drug Administration (FDA), the presence of Hist levels above $500 \mathrm{mg} \mathrm{kg}^{-1}$ in tuna fish samples is toxic to human health. European Union (EU), in turn, set a lower limit of $100-200 \mathrm{mg} \mathrm{kg}^{-1}$ of Hist in the family Scombridae (Altieri, Semeraro, Scalise, Calderari, \& Stacchini, 2016). BAs quantification is very challenging, mainly due to $i$ ) its strong polar character resulting in greater solubility in water than in most organic solvents; ii) the lack of intrinsic properties enabling BAs detection by usual methods (spectrophotometric, fluorometric or electrochemical); iii) matrix sample complexity (presence of many interfering compounds); and iv) simultaneous occurrence of several BAs with variable concentration ranges (from very low to very high).

Chromatographic techniques are usually used for BAs separation and quantification in food matrices. The European Food Safety Authority (EFSA) recommends the use of high performance liquid chromatography (HPLC) with pre- or post-column derivatization and fluorescence (FLD), UV or electrochemical detection, pointing it as a high sensitivity and reliable method (Esatbeyoglu, Ehmer, Chaize, \& Rimbach, 2016). BAs derivatization adds a detectable group to the free amines, therefore improving the method sensitivity, and so continues to be a good alternative (Milheiro, Ferreira, Filipe-Ribeiro, Cosme, \& Nunes, 2019). Several derivatization agents are often used, as benzoyl chloride $(\mathrm{BzCl})$, DnsCl, o-phthalaldehyde (OPA) and fluorescein (Pereira et al., 2017, pp. 1-23). OPA has a short life span, while $\mathrm{BzCl}$ only allows the derivatization of primary and secondary amines. DnsCl, however, is able to derivatize also tertiary amines (Pereira et al., 2017, pp. 1-23), being therefore the reagent with broader range of application for BAs derivatization. There are, nevertheless, alternative methodologies for BAs analysis, not involving derivatization, as the ones proposed by Self, Wu, and Marks (2011) or more recently, Dong and Xiao (2017), using UHPLC-MS/MS approaches. However, the high costs necessary to the MS/MS equipment's acquisition constitute an important obstacle to the implementation of this methodology.

Considering the general interest of the risk assessment of BAs presence in foods, we aimed to develop an improved analytical approach to evaluate their occurrence in different types of commercial tuna fish samples (fresh, frozen, and canned). Thus, the concentration of most relevant BAs (tryptamine, cadaverine, putrescine, spermine, histamine, tyramine, and spermidine) was determined using ultrasound-assisted microextraction (USA $\mu \mathrm{ET}$ ) followed by BAs derivatization with $\mathrm{DnsCl}$ and UHPLC-FLD chromatographic separation. Accordingly, several relevant experimental parameters were optimized, namely $i$ ) the extraction efficiency (ultrasound (US) agitation time, extracting solvent, partitioning salts and buffer solutions); $i$ ) the derivatization procedure (concentration of the derivatization reagent - $\mathrm{DnsCl}$, derivatization time and temperature, and US agitation); and iii) the chromatographic resolution (mobile phase, column and temperature).

\section{Material and methods}

\subsection{Reagents and standards}

All reagents used in this work were used at maximum purity available (analytical or HPLC grade) and the \% of purity is mentioned next to each reagent and solvent list, which includes: orthophosphoric acid $\left(\mathrm{H}_{3} \mathrm{PO}_{4}, 85 \%\right.$, AnalaR), formic acid $\left(\mathrm{CH}_{2} \mathrm{O}_{2}, 98 \%\right.$, Panreac; Barcelona, Spain), sodium tetraborate decahydrate $\left(\mathrm{Na}_{2} \mathrm{~B}_{4} \mathrm{O}_{7} \cdot 10 \mathrm{H}_{2} \mathrm{O}, 99.5 \%\right.$, Riedel-de Haën), DnsCl $\left(\mathrm{C}_{12} \mathrm{H}_{12} \mathrm{ClNO}_{2} \mathrm{~S}, 99 \%\right.$, Sigma-Aldrich; St. Louis, MO, USA), sodium hydroxide ( $\mathrm{NaOH}, 98 \%$, Panreac; Barcelona, Spain), sodium chloride ( $\mathrm{NaCl}, 99.5 \%$, Panreac; Barcelona, Spain), magnesium sulphate anhydrous $\left(\mathrm{MgSO}_{4}, 96 \%\right.$, Panreac; Barcelona, Spain), trisodium citrate dihydrate $\left(\mathrm{C}_{6} \mathrm{H}_{9} \mathrm{Na}_{3} \mathrm{O}_{9} \cdot 2 \mathrm{H}_{2} \mathrm{O}, 99 \%\right.$, Sigma-Aldrich; St. Louis, MO, USA), sodium acetate trihydrate $\left(\mathrm{CH}_{3} \mathrm{CO}_{2} \mathrm{Na} \cdot 3 \mathrm{H}_{2} \mathrm{O}, 99 \%\right.$, Panreac; Barcelona, Spain), sodium hydrogencitrate sesquihydrate $\left(\mathrm{C}_{6} \mathrm{H}_{6} \mathrm{Na}_{2} \mathrm{O}_{7} \cdot 1.5 \mathrm{H}_{2} \mathrm{O}, 99 \%\right.$, Sigma-Aldrich; St. Louis, MO, USA), acetone, acetonitrile (ACN) and methanol $(\mathrm{MeOH})$ (HPLC grade from Fisher Chemical; Loughborough, UK). BAs (cadaverine, histamine, putrescine, spermidine, spermine and tyramine) and 1,7-diaminoheptane (internal standard, IS) were purchased from Acros Organics (Loughborough, UK), while tryptamine was purchased from Alfa Aesar (Kandel, Germany). Ultrapure water $\left(18 \mathrm{M} \Omega \mathrm{cm}\right.$ at $23^{\circ} \mathrm{C}$ ) was prepared using a Milli-Q water purification system (Millipore, Milford, MA, USA). In this work, all the solvents were filtered using a $0.20 \mu \mathrm{m}$ Grace Membrane nylon filter and all solutions and extracts were filtered using a BGB syringe filter, PTFE, $0.2 \mu \mathrm{m}$ purchased by SPECANALITICA ( $\phi 4 \mathrm{~mm}$ Lisbon, Portugal).

\subsection{Tuna fish samples}

Triplicates from seven tuna fish sample types, fresh $(\mathrm{N}=7$, acquired in the day of analysis and keep at $\left.4{ }^{\circ} \mathrm{C}\right)$ and frozen $(\mathrm{N}=7$, conserved at $-20^{\circ} \mathrm{C}$ ) tuna $(85 \mathrm{~g}$ of each, both from Thunnus obesus specie acquired in a local fishery market and fished in the Atlantic Ocean, in the Portuguese maritime zone) and triplicates of commercial canned tuna (in oil, olive oil, natural and pate, canned with $85 \mathrm{~g}$ of tuna), from unspecified tuna species and purchased in different markets located at Funchal, Madeira Island, Portugal), were analysed in this study. The different parts of the fresh tuna fish were separated and only the white muscle (wm) and dark muscle $(\mathrm{dm})$ were used. After maceration and grounded to a homogenous paste they were aliquoted and stored at $-20^{\circ} \mathrm{C}$. The oil, olive oil and water present in the canned samples were discarded before processing the sample. Regardless of the sample type, $1 \mathrm{~g}$ of homogenous tuna samples was used in the different assays. All samples were analysed in triplicate $(n=3)$ and the results were expressed with the mean of the measurements. The experimental layout followed in this study is shown in Fig. 2.

\subsection{Standard solutions}

BAs stock solutions were prepared in $0.1 \%$ formic acid (FA) at $25 \mathrm{mg}$ $\mathrm{mL}^{-1}$ and the pooled standard solutions containing all BAs were prepared by aliquot dilution (Concentration Range: Put $5-750 \mathrm{mg} \mathrm{kg}{ }^{-1}$, 


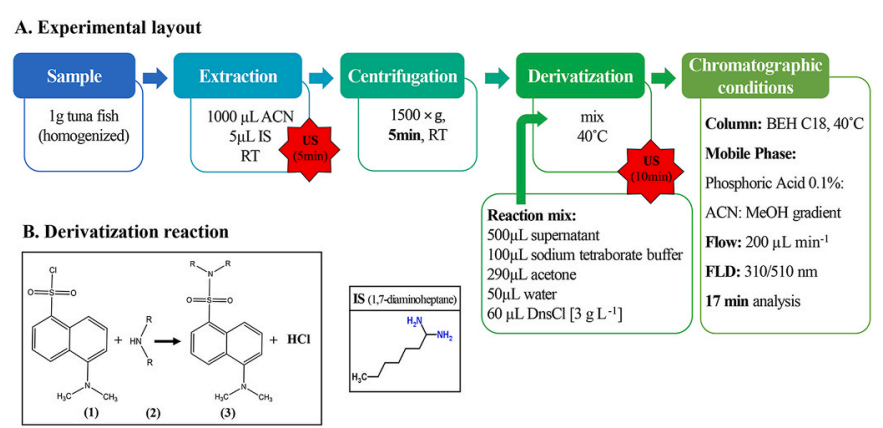

Fig. 2. Summary of the optimized experimental procedure (A) and dansyl derivatization (B). ACN - acetonitrile; DnsCl - dansyl chloride; FLD - fluorescent detection; IS - internal standard; $\mathrm{MeOH}$ - methanol; US - ultrasound.

Try, Cad, Spermine (Spm), Hist, and Spermidine (Spd) 25-750 $\mathrm{mg} \mathrm{kg}^{-1}$; Tyrm 125-750 mg kg ${ }^{-1}$ - lower limits for Put and Tyrm are different from remaining BAs to match the detection levels that Put and Tyrm can be detected in food matrices). All BAs solutions were stored refrigerated at $4{ }^{\circ} \mathrm{C}$ and prepared from stock solutions every week. The internal standard (IS, 1,7-diaminoheptane) stock solution was prepared at $2 \mathrm{mg}$ $\mathrm{L}^{-1}$ in $0.1 \% \mathrm{FA}$. The dansyl chloride ( $\mathrm{DnsCl}$ ) solution was prepared at 50 $\mathrm{mg} \mathrm{mL}^{-1}$ in acetone just before use.

\subsection{USA $\mu E T$ optimization}

The USA $\mu$ ET optimization was carried out using wm and different experimental conditions, namely the US agitation time $(0,1,5,10 \mathrm{~min}$ using a Branson 2510, $100 \mathrm{~W}$ US bath), the nature of the extracting solvent (ACN and $\mathrm{MeOH}$ ), the partitioning salts (sodium chloride and magnesium sulphate) and the use of buffers solutions (acetate and citrate buffers as indicated in the Supplementary Table 1.SM, and according to previous work (Porto-Figueira, Camacho, \& Câmara, 2015)). The extraction process was performed with $1 \mathrm{~g}$ aliquots, $1 \mathrm{~mL}$ of ACN and $5 \mu \mathrm{L}$ of 1,7 -diaminoheptane at $2 \mathrm{mg} \mathrm{mL}^{-1}$. The mixture was vortexed and placed $5 \mathrm{~min}$ in the US at $23^{\circ} \mathrm{C}$. Finally, it was centrifugated ( $1500 \times g$, $5 \mathrm{~min}$, room temperature) and the supernatant used for the following derivatization procedure. All conditions assayed are detailed in the Supplementary Table 1.

\subsection{Derivatization procedure}

Several experimental parameters, DnsCl concentration (1, 2, $3 \mathrm{mg}$ $\left.\mathrm{mL}^{-1}\right)$, derivatization time, US agitation $(0,10,20 \mathrm{~min})$ and temperature $\left(23,40,60{ }^{\circ} \mathrm{C} \pm 1{ }^{\circ} \mathrm{C}\right)$, were optimized to simplify BAs derivatization. After the extraction step, $500 \mathrm{~mL}$ of the supernatant were removed and added $290 \mu \mathrm{L}$ acetone, $50 \mu \mathrm{L}$ ultrapure water, $100 \mu \mathrm{L}$ tetraborate buffer $\left(0.1 \mathrm{~mol} \mathrm{dm}^{-1}\right)$ and $60 \mu \mathrm{L}$ of DnsCl (Fig. 2A). The reaction mixture was stirred in the vortex and subjected to US for 0,10 or $20 \mathrm{~min}$, at different temperatures. The conditions assayed are detailed in Supplementary Table 2. Finally, the solution was filtered, diluted in acidified water $(0.1 \% \mathrm{FA}, 1: 2)$ and injected in the UHPLC for analysis. The chromatographic conditions assayed are indicated in Fig. 3A.

\subsection{Chromatographic conditions}

The chromatographic analysis was performed with the Waters UHPLC Chromatograph equipped PDA and FLD. The resolution of the chromatographic separation was evaluated with the columns Acquity UPLC BEH C18 $(50 \times 2.1 \mathrm{~mm}, 1.7 \mu \mathrm{m})$ and Acquity UPLC CSH C18 (150 $\times 2.1 \mathrm{~mm}, 1.7 \mu \mathrm{m})$. The PDA and FLD were compared to select the one retrieving greater sensitivity for the detection of derivatized BAs. Upon the initial optimization step, the chromatographic separation was performed with the Acquity UPLC BEH C18 column and a three-phase
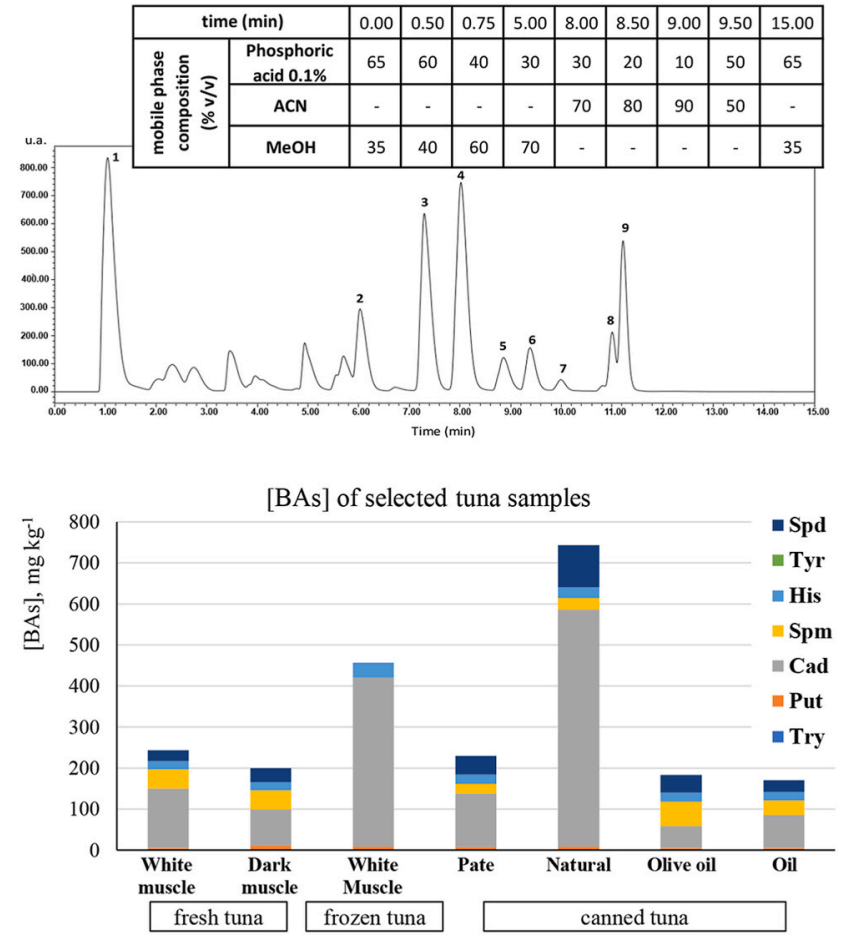

Fig. 3. (A) Representative chromatogram of a standard solution of BAs after derivatization (column Acquity UPLC BEH C18 with FLD; $\lambda_{\mathrm{emi}}=500 \mathrm{~nm}$ and $\lambda_{\text {exc }}=300 \mathrm{~nm}$ ). 1 - DnsCl; 2 - Try; 3 - Put; 4 - Cad; 5 - Spm; 6 - Hist; 7 - IS; 8 Tyrm; 9 - Spd. (B) BAs profile found in canned (pate, natural; Olive oil and oil) fresh and frozen tuna fish samples (RSD $<5 \%$ ). Cad - cadaverine, Put - putrescine, Try - tryptamine, Spm - spermine, Hist - histamine, Tyrm - tyramine, Spd - spermidine; wm - white muscle; dm - dark muscle.

gradient $(0.1 \%$ phosphoric acid, $\mathrm{ACN}$ and $\mathrm{MeOH})$ at a flow rate of $0.200 \mathrm{~mL} / \mathrm{min}$, with a $15 \mathrm{~min}$-run and a 2 min-reconditioning step (Fig. 3A). The column temperature was $40{ }^{\circ} \mathrm{C}$ and the injection volume $2 \mu \mathrm{L}$. FLD (300 nm excitation/500 $\mathrm{nm}$ emission lengths) was selected to analyse the target BAs. The data obtained was processed using Empower 2 software (Waters).

\subsection{Method validation}

Validation was performed according to the international guidelines (COMMISSION REGULATION (EC), 2002; FAO/WHO, 2013) and selectivity, linearity $\left(\mathrm{R}^{2}\right)$, detection (LOD) and quantification (LOQ) limits, precision, recovery (\%) and matrix effect (ME). Selectivity was assessed by comparing chromatograms of solvent, white muscle (wm) and wm with added BAs and IS. To evaluate the method linearity, BAs standard solutions (Table 2) were prepared in $0.1 \% \mathrm{FA}$ and used to obtain the calibration curve. All solutions were injected 5 times, under repeatability conditions. Sensitivity was evaluated by measuring the detection (LOD) and quantification (LOQ) limits for each analyte using the residual standard deviation $\left(\mathrm{s}_{\mathrm{y} / \mathrm{x}}\right)$ of corresponding calibration curves. LOD and LOQ were calculated as $3.3 \mathrm{~s}_{\mathrm{y} / \mathrm{x}} / \mathrm{b}$ and $10 \mathrm{~s} / \times / \mathrm{b}$, respectively, where $s_{y / \times}$ represents the standard deviation of ordinate at origin and $\mathrm{b}$ the slope of the regression line, as described in Porto-Figueira et al. (2015). Precision was evaluated by adding to the wm samples three concentration levels of each BAs (low - LL, medium - ML, and high - HL, concentration points of the calibration curve - Table 2). Five replicates $(n=5)$ were carried out in the same day or in three consecutive days (total $n=15$ ) to calculate intra-day and inter-day precisions, respectively. Recovery was carried out by comparison between a mix of standard solutions ( $\mathrm{LL}, \mathrm{ML}$ and $\mathrm{HL}$ ) of each BAs and wm samples added with the same amounts of BAs. The concentrations LL, 
ML and HL were used to obtain the calibration curves for each BA with five replicates each $(n=5)$. ME were calculated as the ratio of the slopes of the analytical curves obtained for the analytical standard solutions prepared in solvent and in $\mathrm{wm}, \mathrm{ME}=[(\mathrm{y} / \times$ solvent $) /(\mathrm{y} / \times$ spiked wm)] $\times 100$ (Perestrelo, Petronilho, Câmara, \& Rocha, 2010).

\subsection{Quality index}

Mietz and Karmas (1977) observed that the presence of Hist, Put and Cad in fresh tuna fish samples is low, increasing concomitantly with sample deterioration. In contrast, Spd and Spm follow the opposite trend, decreasing along with deterioration. Taking this into consideration, these authors implemented a quality index (QI) based on the concentration of the referred BAs in $\mathrm{mg} \mathrm{kg}^{-1}$, according to equation (1) (Mietz \& Karmas, 1977):

Quality index $=\frac{[\text { histamine }]+[\text { putrescine }]+[\text { cadaverine }]}{1+[\text { spermidine }]+[\text { spermine }]}$

As a result, high levels of Spd and Spm conjugated with low values of Put, Cad and Hist are indicators of good quality, while the inverse indicates tuna decomposition. Thus, QI values below 1 correspond to a good quality of the tuna sample, being safe for human consumption. QI values between 1 and 10 indicate poor quality and decomposition above 10.The grade decomposition is obviously unsafe for human consumption.

\subsection{Statistical analysis}

Results were expressed as mean \pm standard deviation (SD) of the independent experiments. Differences among samples were estimated by analysis of variance (ANOVA) followed by Tukey's 'honest significant difference' test. The statistical significance level was set to $p$-values $<0.05$. All statistical analyses were performed using Statistica software (TIBCO Software Inc).

\section{Results and discussion}

\subsection{Definition of the best experimental layout}

The absence of natural chromophores in most BAs requires their derivatization to allow a reliable chromatographic analysis. In this work, $\mathrm{DnsCl}$ was select as the derivatization reagent since allows the derivatization of primary, secondary, and tertiary amines. Upon a literature survey of chromatographic methods for the analysis of dansylated BAs, we observed a lack of optimization of the derivatization reaction at several levels, particularly in what concerns to the sample amount and reaction conditions ( $\mathrm{DnsCl}$ concentration, reaction time and temperature; see Table 1).

Our preliminary assays involved the BAs dansylation previously to the acidic extraction. However, this approach did not retrieve satisfactory results, maybe due to the low affinity of the dansylated BAs to the extraction system and was discarded. Therefore, we optimized an experimental layout involving US-assisted extraction under acidic conditions, followed by BAs dansylation, chromatographic separation and data analysis (see Fig. 2). To normalize the chromatographic data obtained and allow an accurate comparison of the experimental conditions assayed, 1,7-diaminoheptane was used as IS. The best conditions found in each optimization step are summarized in the Supplementary Fig. 1 and detailed in the following sections.

\subsection{Optimization of extractive conditions by ultrasound-assisted microextraction (USA $\mu E T)$}

To achieve the best extraction conditions, the influence of US extraction time (0, 1, 5 and $10 \mathrm{~min}$ ) and solvents (ACN, MEOH and ACN: $\mathrm{MeOH}(1: 1)$ ) were thoroughly assayed. The best results were obtained with a 5 min USA $\mu$ ET and ACN as extraction solvent (Supplementary Fig. 1.SM). Additionally, we also assayed the effect of salts ( $\mathrm{NaCl}$ and $\mathrm{MgSO}_{4}$ ) and buffers (acetate and citrate buffers) on the extraction efficiency. However, none of these conditions retrieved higher extraction efficiencies (Supplementary Fig. 2.SM).

\subsection{Optimization of derivatization conditions with dansyl chloride (DnsCl)}

Derivatization was also optimized at several levels, namely DnsCl concentration, reaction time and temperature, and the use of US. This optimization was justified by the disparity in the derivatization conditions reported in the literature involving similar applications (Table 1). According to the obtained results (Supplementary Fig. 1.SM), both the increase of DnsCl concentration and derivatization temperature favour the derivatization procedure. In turn, the effect of US is less obvious as higher relative areas were obtained without the use of US at $60{ }^{\circ} \mathrm{C}$. However, we observed that the use of $60^{\circ} \mathrm{C}$ during the derivatization reaction is not recommended since this temperature is very close to the boiling point of acetone, the main constituent (reagent) of this reaction, which is $56^{\circ} \mathrm{C}$. Consequently, part of the acetone evaporates during the derivatization reaction affecting the reproducibility of the results. Possibly the higher relative areas obtained at $60{ }^{\circ} \mathrm{C}$ (Supplementary Fig. 3) may have a partial contribution of this concentration effect. Therefore, the assay of $60{ }^{\circ} \mathrm{C}$ as a derivatization temperature was abandoned in the following experiments. Overall, the best conditions obtained for the BAs derivatization were $3 \mathrm{mg} \mathrm{mL}^{-1}$ of DnsCl, with a US time of $10 \mathrm{~min}$ at $40{ }^{\circ} \mathrm{C}$ (Supplementary Fig. 3.SM).

\subsection{Chromatographic conditions}

To obtain the best chromatographic separation of the dansylated BAs, several instrumental conditions were evaluated. Additionally, a preliminary assessment of the suitable detector for the analysis of the derivatized BAs unequivocally shown that the $\mathrm{S} / \mathrm{N}$ ratio is much higher using the FLD instead of PDA detector (Fig. 4.SM). The selection of the appropriate chromatographic column was limited by the high $\mathrm{pH}$ variations that the samples are subject during extraction and derivatization steps. Accordingly, the Acquity UPLC CSH C18 and the Acquity UPLC BEH C18 columns, which can withstand broad $\mathrm{pH}$ variations (1-11 and $1-12$, respectively) were assayed throughout the optimization of the chromatographic separation. This included the selection of a mobile phase gradient and flow rate able to deliver a fast and efficient chromatographic separation. The best results were obtained using a $200 \mu \mathrm{L} /$ min of a three-phase gradient composed by $0.1 \%$ phosphoric acid, ACN and $\mathrm{MeOH}$, as described in Fig. 3A. Regarding the selection of the best column, the Acquity UPLC BEH C18 allowed a better chromatographic resolution of the dansylated BAs (Fig. 3A).

\subsection{Validation of the analytical methodology for the determination of selected BAs in tuna fish samples}

The USA $\mu \mathrm{ET} / \mathrm{UHPLC}$-FLD methodology developed was validated for the quantification of selected BAs in tune fish samples. This involved the evaluation of selectivity, linearity, LOD, LOQ, precision, recovery, and matrix effect (Table 2). Overall, a good analytical performance is reported for the quantification of the dansylated BAs within the linear range of concentrations indicated in Table 2. The determination coefficients $\left(R^{2}\right)$ obtained were above 0.9993, except for Cad (0.9809), Hist (0.9887) and Tyrm (0.9877) (Table 2). This minor variation was most probably caused by an unidentified error in the several experimental steps involved in the methodology, particularly the derivatization process.

The LODs and LOQs obtained varied between $0.98 \mathrm{mg} \mathrm{kg}^{-1}$ and 8.57 $\mathrm{mg} \mathrm{kg}^{-1}$ and between $3.20 \mathrm{mg} \mathrm{kg}^{-1}$ and $25.6 \mathrm{mg} \mathrm{kg}^{-1}$, for Put and Tyrm, respectively, being in the same range of other methodologies reported in 
Table 1

Methodologies reported in the literature for the analysis and quantification of BAs in foodstuffs.

\begin{tabular}{|c|c|c|c|c|c|c|c|c|}
\hline \multicolumn{2}{|c|}{ Method/Equipment } & LDR (mg kg $\left.{ }^{-1}\right)$ & \multicolumn{3}{|l|}{ LOQ (mg kg $\left.{ }^{-1}\right)$} & \multicolumn{2}{|l|}{ Total time (min) } & Reference \\
\hline \multicolumn{2}{|c|}{ AOAC/Fluorometer } & $1-150$ & $1-5$ & & & \multicolumn{2}{|l|}{$60-120$} & \multirow[t]{5}{*}{ FAO/WHO (2013) } \\
\hline \multicolumn{2}{|c|}{$\begin{array}{l}\text { Spectrofluorometric/ } \\
\text { Spectrofluorometer }\end{array}$} & $0.0015-100$ & \multicolumn{3}{|l|}{$1.5\left(\mu \mathrm{g} \mathrm{kg}^{-1}\right)$} & 60 & & \\
\hline \multicolumn{2}{|c|}{ ELISA/Spectrofluorometer } & $0-500$ & \multicolumn{3}{|l|}{$2-5$} & \multicolumn{2}{|l|}{60} & \\
\hline \multicolumn{2}{|c|}{$\begin{array}{l}\text { Colorimetric/ } \\
\text { Spectrofluorometer }\end{array}$} & $0.8-300$ & \multicolumn{3}{|l|}{20} & \multicolumn{2}{|l|}{60} & \\
\hline Chromatog & iphic (LC) & $5-2500$ & $1.5-5$ & & & $60-120$ & & \\
\hline \multicolumn{9}{|c|}{ Chromatographic methods with pre-column derivatization - DnsCl } \\
\hline $\begin{array}{c}\text { DnsCl } \\
\text { (mg/ } \\
\text { mL)/ } \\
\text { deriv. } \\
\text { time } \\
\text { (min) }\end{array}$ & $\begin{array}{l}\text { Extraction } \\
\text { conditions }\end{array}$ & $\begin{array}{l}\text { Methodology } \\
\text { (column, } \\
\text { wavelength) }\end{array}$ & $\begin{array}{l}\text { Sample } \\
\text { amount }\end{array}$ & Identified BAs & LDR & $\begin{array}{l}\text { LODs/LOQs } \\
\text { (units) }\end{array}$ & $\begin{array}{l}\text { Analysis } \\
\text { time (min) }\end{array}$ & References \\
\hline $3 / 10$ & US, $40{ }^{\circ} \mathrm{C}$, SLE & $\begin{array}{l}\text { UHPLC-FLD (BEH } \\
\mathrm{C} 18, \lambda_{\mathrm{emi}}= \\
500 \mathrm{~nm} / \lambda_{\text {exc }}=300 \\
\mathrm{~nm})\end{array}$ & Tuna fish (1 g) & $\begin{array}{l}\text { Cad, Hist, Put, Spd, } \\
\text { Spm, Try, Tyrm }\end{array}$ & $\begin{array}{l}5-750 \mathrm{mg} \\
\mathrm{kg}^{-1}\end{array}$ & \multicolumn{2}{|l|}{$\begin{array}{l}0.98-8.57 / \\
3.20-25.64 \mathrm{mg} \\
\mathrm{kg}^{-1}\end{array}$} & This work \\
\hline$-/ 5^{d}$ & Dark, $60{ }^{\circ} \mathrm{C}$, SLE & $\begin{array}{l}\text { HPLC-UV (Kromasil } \\
\text { C18, } \lambda=254 \mathrm{~nm} \text { ) }\end{array}$ & Fish $(5 \mathrm{~g})$ & $\begin{array}{l}\text { Cad, Hist, Phe, Put, } \\
\text { Spd, Spm, Try, Tyrm }\end{array}$ & $\begin{array}{l}25-250 \mathrm{mg} \\
\mathrm{kg}^{-1}\end{array}$ & - & 90 & Duflos et al. (2019) \\
\hline $7.5 / 5^{\mathrm{d}}$ & $\begin{array}{l}\text { Vortex, D ark, } \\
60^{\circ} \mathrm{C} ; \mathrm{LLE}\end{array}$ & $\begin{array}{l}\text { HPLC-UV (Kromasil } \\
\text { C18, } \lambda=254 \mathrm{~nm} \text { ) }\end{array}$ & $\begin{array}{l}\text { Eggs ( } 3 \text { g yolk, } \\
\text { albumen) }\end{array}$ & $\begin{array}{l}\text { Cad, Hist, Phe, Put, } \\
\text { Spd, Spm, Tyrm }\end{array}$ & $\begin{array}{l}0.7-22.4 \\
\mathrm{mg} \mathrm{kg}^{-1}\end{array}$ & \multicolumn{2}{|l|}{$\begin{array}{l}0.2-0.3 / \\
0.7-1.0 \mathrm{mg} \mathrm{kg}^{-1} \\
\text { (yolk) } \\
0.2-0.4 / \\
0.7-1.1 \mathrm{mg} \mathrm{kg}^{-1} \\
\text { (albumen) }\end{array}$} & $\begin{array}{l}\text { de Figueiredo et al. } \\
\text { (2015) }\end{array}$ \\
\hline $7.5 / 5^{\mathrm{d}}$ & $\begin{array}{l}\text { Dark, Bath, } \\
60^{\circ} \mathrm{C} \text {; SLE }\end{array}$ & $\begin{array}{l}\text { HPLC-UV (Kromasil } \\
\text { C18, } \lambda=254 \mathrm{~nm} \text { ) }\end{array}$ & Chicken (5 g) & $\begin{array}{l}\text { Cad, Hist, Put, Spd, } \\
\text { Spm, Tyrm }\end{array}$ & $\begin{array}{l}0.9-94.4 \\
\mathrm{mg} \mathrm{kg}^{-1}\end{array}$ & $\begin{array}{l}0.3 / 0.9-1 \mathrm{mg} \\
\mathrm{kg}^{-1}\end{array}$ & 210 & Assis et al. (2016) \\
\hline $10 / 45^{\mathrm{d}}$ & $40^{\circ} \mathrm{C}$; SLE & $\begin{array}{l}\text { HPLC-UV } \\
\text { (Spherisorb ODS2 } \\
150 \mathrm{~A}, \lambda=254 \mathrm{~nm} \text { ) }\end{array}$ & Fish $(2 \mathrm{~g})$ & $\begin{array}{l}\text { Cad, Hist, Put, Try, } \\
\text { Tyrm }\end{array}$ & - & $\begin{array}{l}0.005-0.050 / \\
0.010-0.100 \mu \mathrm{g} \\
\mathrm{mL}^{-1}\end{array}$ & 120 & $\begin{array}{l}\text { Bilgin and Gençcelep } \\
\text { (2015) }\end{array}$ \\
\hline $10 / 45^{\mathrm{d}}$ & $40^{\circ} \mathrm{C}$; SLE & $\begin{array}{l}\text { HPLC-UV } \\
\text { (COSMOSIL 5C18- } \\
\text { PAQ, } \lambda=254 \mathrm{~nm} \text { ) }\end{array}$ & Carp (5 g) & $\begin{array}{l}\text { Cad, Hist, Phe, Put, } \\
\text { Spd, Spm, Try, Tyrm }\end{array}$ & - & - & 170 & $\begin{array}{l}\text { Li, Li, Qin, Hong, and } \\
\text { Luo (2016) }\end{array}$ \\
\hline $10 / 30^{\mathrm{d}}$ & $60^{\circ} \mathrm{C}$; SPE & $\begin{array}{l}\text { HPLC-UV }(\mathrm{C} 18, \lambda= \\
254 \mathrm{~nm})\end{array}$ & Salami (5 g) & Cad, Put, Spm, Tyrm & - & $\begin{array}{l}0.05-0.1 /-\mathrm{mg} \\
\mathrm{kg}^{-1}\end{array}$ & 130 & Loizzo et al. (2016) \\
\hline $10 / 10^{\mathrm{d}}$ & $70^{\circ} \mathrm{C}$; SPE & $\begin{array}{l}\text { HPLC-UV (C18 ODS } \\
\text { Hypersil, } \lambda=254 \\
\mathrm{~nm})\end{array}$ & Food (5 g) & $\begin{array}{l}\text { Cad, Hist, Phe, Put, } \\
\text { Spd, Try, Tyrm }\end{array}$ & $\begin{array}{l}0.001-50 \\
\mathrm{mg} \mathrm{L}^{-1}\end{array}$ & $\begin{array}{l}0.02-0.06 / \\
0.07-0.13 \mu \mathrm{g} \\
\mathrm{L}^{-1}\end{array}$ & 160 & Tameem et al. (2010) \\
\hline $10 / 45$ & $\begin{array}{l}\text { US- } \\
\text { trichloroacetic } \\
\text { acid extraction }\end{array}$ & $\begin{array}{l}\text { HPLC-DAD (Zorbax } \\
\text { Eclipse plus C18, } \\
254 \mathrm{~nm} \text { ) }\end{array}$ & $\begin{array}{l}\text { skipjack tuna } \\
(10 \mathrm{~g})\end{array}$ & $\begin{array}{l}\text { Cad, Hist, Put, Spd, } \\
\text { Spm, Tryp }\end{array}$ & $\begin{array}{l}3-30 \mathrm{mg} \\
\mathrm{L}^{-1}\end{array}$ & $\begin{array}{l}0.05-0.24 / \\
0.18-1.23 \mathrm{mg} \\
\mathrm{kg}^{-1}\end{array}$ & & Barbosa et al. (2018) \\
\hline $2 / 45^{d}$ & Shake, $40^{\circ} \mathrm{C}$; SLE & $\begin{array}{l}\text { HPLC-UV } \\
\text { (Spherisorb ODS2, } \lambda \\
=254 \mathrm{~nm} \text { ) }\end{array}$ & $\begin{array}{l}\text { Fermented } \\
\text { sausages (2 g) }\end{array}$ & $\begin{array}{l}\text { Cad, Hist, Phe, Put, } \\
\text { Spd, Spm, Try, Tyrm }\end{array}$ & - & - & 130 & Ekici and Omer (2018) \\
\hline $10 / 45^{\mathrm{d}}$ & $40^{\circ} \mathrm{C}$; SLE & $\begin{array}{l}\text { HPLC-UV (Nova-Pak } \\
\text { C18, } \lambda=254 \mathrm{~nm} \text { ) }\end{array}$ & Food $(5 \mathrm{~g})$ & $\begin{array}{l}\text { Cad, Hist, Phe, Put, } \\
\text { Spd, Spm, Try, Tyrm }\end{array}$ & $\begin{array}{l}25-1000 \\
\mathrm{mg} \mathrm{kg}^{-1}\end{array}$ & $\begin{array}{l}0.01-0.10 / \\
0.02-0.31 \mathrm{mg} \\
\mathrm{kg}^{-1}\end{array}$ & 230 & (Yoon et al., 2015) \\
\hline$-/ 60^{d}$ & $45^{\circ} \mathrm{C}$; SLE & $\begin{array}{l}\text { HPLC-FLR (ODS-3, } \\
\lambda_{\mathrm{emi}}=525 \mathrm{~nm} / \lambda_{\mathrm{exc}} \\
=325 \mathrm{~nm})\end{array}$ & Seafood (10 g) & Hist & $\begin{array}{l}0.4-200 \\
\mathrm{mg} \mathrm{L}^{-1}\end{array}$ & $2.5 /-\mathrm{mg} \mathrm{L}^{-1}$ & 110 & Yoshida et al. (2012) \\
\hline $10 / 55^{\mathrm{d}}$ & $\begin{array}{l}40{ }^{\circ} \mathrm{C} \text {, cooled } 10 \\
\mathrm{~min}, \mathrm{SLE}\end{array}$ & $\begin{array}{l}\text { HPLC-UV (Eclipse } \\
\text { XBD C18, } \lambda=254 \\
\mathrm{~nm} \text { ) }\end{array}$ & Fish $(5 g)$ & Hist & $\begin{array}{l}30-700 \mathrm{mg} \\
\mathrm{kg}^{-1}\end{array}$ & $3 / 10 \mathrm{mg} / \mathrm{kg}$ & 140 & Altieri et al. (2016) \\
\hline $5 / 60^{\mathrm{d}}$ & $\begin{array}{l}\text { Vortex, Dark } \\
45^{\circ} \mathrm{C}, \mathrm{SPE}\end{array}$ & $\begin{array}{l}\text { HPLC-UV (Eclipse } \\
\text { XBD C18, } \lambda=254 \\
\mathrm{~nm} \text { ) }\end{array}$ & $\begin{array}{l}\text { Sausage and } \\
\text { cheese ( } 50 \mathrm{~g})\end{array}$ & $\begin{array}{l}\text { Cad, Hist, Phe, Put, } \\
\text { Spd, Spm, Try,Tyrm }\end{array}$ & $\begin{array}{l}0.18-500 \\
\mathrm{mg} \mathrm{kg}^{-1}\end{array}$ & $\begin{array}{l}0.03-0.36 / \\
0.11-1.19 \mathrm{mg} \\
\mathrm{kg}^{-1}\end{array}$ & 120 & Liu et al. (2018) \\
\hline \multicolumn{9}{|l|}{ OPA } \\
\hline$-1-$ & $\begin{array}{l}\text { Post-column, RT, } \\
\text { SLE }\end{array}$ & $\begin{array}{l}\text { Ion- pair HPLC-FLR } \\
\text { (Nova-Pak C18, } \lambda_{\text {emi }} \\
=450 \mathrm{~nm} / \lambda_{\mathrm{exc}}= \\
340 \mathrm{~nm} \text { ) }\end{array}$ & Fish (5 g) & $\begin{array}{l}\text { Agm, Cad, Hist, Phe, } \\
\text { Put, Ser, Spd, Spm, } \\
\text { Try,Tyrm }\end{array}$ & $\begin{array}{l}1-250 \mathrm{mg} \\
\mathrm{kg}^{-1}\end{array}$ & $\begin{array}{l}0.03 / 0.09 \mathrm{mg} \\
\mathrm{kg}^{-1}\end{array}$ & 60 & $\begin{array}{l}\text { Evangelista et al. } \\
\text { (2016) }\end{array}$ \\
\hline $40 /-$ & $\begin{array}{l}\text { Post-column, RT, } \\
\text { LLE/SLE }\end{array}$ & $\begin{array}{l}\text { UHPLC-FLR }(\text { BEH } \\
\mathrm{C} 18, \lambda_{\text {emi }}=445 \mathrm{~nm} / \\
\left.\lambda_{\text {exc }}=340 \mathrm{~nm}\right)\end{array}$ & $\begin{array}{l}\text { Wine, fish, } \\
\text { cheese and dry } \\
\text { sausage (5-10 } \\
\text { g) }\end{array}$ & $\begin{array}{l}\text { Agm, Cad, Dop, Hist, } \\
\text { Oct, Phe, Put, Ser } \\
\text { Spd, Spm, Try, Tyrm }\end{array}$ & $\begin{array}{l}0.1-50 \mathrm{mg} \\
\mathrm{L}^{-1}\end{array}$ & - & 80 & $\begin{array}{l}\text { Latorre-Moratalla et al. } \\
\text { (2009) }\end{array}$ \\
\hline \multicolumn{9}{|l|}{$\mathrm{BzCl}$} \\
\hline $36.3 / 30^{*}$ & US Bath, SPE & $\begin{array}{l}\text { HPLC-UV (Eclipse } \\
\text { XDB-C18, } \lambda=254 \\
\mathrm{~nm} \text { ) }\end{array}$ & $\begin{array}{l}\text { Sausage and } \\
\text { cheese ( } 5 \mathrm{~g})\end{array}$ & $\begin{array}{l}\text { Cad, Hist, Phe, Put, } \\
\text { Spd, Spm, Try,Tyrm }\end{array}$ & $\begin{array}{l}0.29-500 \\
\mathrm{mg} \mathrm{kg}^{-1}\end{array}$ & $\begin{array}{l}0.09-0.38 / \\
0.29-1.26 \mathrm{mg} \\
\mathrm{kg}^{-1}\end{array}$ & 70 & Liu et al. (2018) \\
\hline$-/ 10$ & Vortex, RT, SLE & $\begin{array}{l}\text { UHPLC-MS } \\
\text { (ACQUITY HSS T3) }\end{array}$ & Fish (20 mg) & $\begin{array}{l}\text { Agm,Cad, Hist, Phe, } \\
\text { Put, Spd, Spm, Try, } \\
\text { Tyrm }\end{array}$ & $\begin{array}{l}5-200000 \\
\text { pg } \mathrm{mL}^{-1}\end{array}$ & $\begin{array}{l}0.1-10.0 / \\
1.0-100.0 \mathrm{pg} \\
\mathrm{mL}^{-1}\end{array}$ & 50 & Lee et al. (2015) \\
\hline
\end{tabular}


Table 1 (continued)

\begin{tabular}{|c|c|c|c|c|c|c|c|c|}
\hline \multicolumn{2}{|c|}{ Method/Equipment } & \multirow{2}{*}{$\begin{array}{l}\text { LDR (mg kg-1) } \\
\text { Methodology } \\
\text { (column, } \\
\text { wavelength) }\end{array}$} & \multicolumn{3}{|l|}{ LOQ (mg kg ${ }^{-1}$ ) } & \multicolumn{2}{|l|}{ Total time (min) } & \multirow{2}{*}{$\begin{array}{l}\text { Reference } \\
\text { References }\end{array}$} \\
\hline $\begin{array}{l}\text { DnsCl } \\
\text { (mg/ } \\
\text { mL)/ }\end{array}$ & $\begin{array}{l}\text { Extraction } \\
\text { conditions }\end{array}$ & & $\begin{array}{l}\text { Sample, } \\
\text { amount }\end{array}$ & Identified BAs & LDR & $\begin{array}{l}\text { LODs/LOQs } \\
\text { (units) }\end{array}$ & $\begin{array}{l}\text { Analysis } \\
\text { time (min) }\end{array}$ & \\
\hline & MSPD & $\begin{array}{l}\text { UHPLC-HILIC (BEH } \\
\text { HILIC) }\end{array}$ & $\begin{array}{l}\text { Canned and } \\
\text { frozen tuna } \\
(0.5 \mathrm{~g})\end{array}$ & $\begin{array}{l}\text { Agm, Cad, Hist, Phe, } \\
\text { Put, Try, Tyr, and } \\
\text { urocanic acid }\end{array}$ & $\begin{array}{l}20-100 \\
(\mathrm{ppm})\end{array}$ & $\begin{array}{l}0.0204-1.57 / \\
0.0680-5.2 \\
(\mathrm{ppm})\end{array}$ & 18 & Self et al. (2011) \\
\hline & $\begin{array}{l}\text { Modified } \\
\text { QuEChERS }\end{array}$ & $\begin{array}{l}\text { UHPLC-MS/MS } \\
\text { (BEH C18) }\end{array}$ & $\begin{array}{l}\text { Soy sauce } \\
(0.500 \mathrm{~g})\end{array}$ & $\begin{array}{l}\text { Hist, Phe, Put, Spm, } \\
\text { Spd, Tyr, Tryp }\end{array}$ & $\begin{array}{l}3.0-600 \\
\left(\mu \mathrm{kg}^{-1}\right)\end{array}$ & $\begin{array}{l}4-8 / 15-30(\mu \mathrm{g} \\
\left.\mathrm{kg}^{-1}\right)\end{array}$ & 4 & Dong and Xiao (2017) \\
\hline & $\begin{array}{l}10 \text { min US, } \\
\text { centrifugation }\end{array}$ & IC-CD & $\begin{array}{l}\text { tuna } \\
\text { fish, anchovies, } \\
\text { wine, olives, } \\
\text { salami, and } \\
\text { cheeses, } 2 \mathrm{~g}\end{array}$ & $\begin{array}{l}\text { Agm, Cad, His, Put, } \\
\text { Spd, Spm, } \\
\text { triethylamine, } \\
\text { trimethylamine }\end{array}$ & $\begin{array}{l}0-200(\mathrm{mg} \\
\left.\mathrm{kg}^{-1}\right)\end{array}$ & $\begin{array}{l}23-65 / 65-198 \\
\left(\mu \mathrm{gg}^{-1}\right)\end{array}$ & - & $\begin{array}{l}\text { Palermo, Muscarella, } \\
\text { Nardiello, Iammarino, } \\
\text { and Centonze (2013) }\end{array}$ \\
\hline & $\begin{array}{l}\text { solvent } \\
\text { extraction }\end{array}$ & $\begin{array}{l}\text { ELISA, HPLC } \\
\text { (Supelcosil LC-ABZ, } \\
210 \mathrm{~nm}), \mathrm{CE}(210 \\
\mathrm{nm})\end{array}$ & $\begin{array}{l}\text { Seafood (ELISA } \\
2 \mathrm{~g} \text {; HPLC, CE, } \\
10 \mathrm{~g})\end{array}$ & Hist & $\begin{array}{l}2.5-200 \\
\left(\mathrm{mg} \mathrm{kg}^{-1}\right)\end{array}$ & $\begin{array}{l}2.5,10(\mu g \\
\left.\mathrm{kg}^{-1}\right)\end{array}$ & $\begin{array}{l}160 \\
\text { (ELISA), } 60 \\
\text { (HPLC), } 25 \\
\text { (CE) }\end{array}$ & $\begin{array}{l}\text { Muscarella, } \\
\text { Iammarino, Centonze, } \\
\text { and Palermo (2005) }\end{array}$ \\
\hline
\end{tabular}

Legend: DnsCl - dansyl chloride, LDR - IEC-CD - ion-exchange chromatography with conductivity detection, MSPD - matrix solid-phase dispersion.

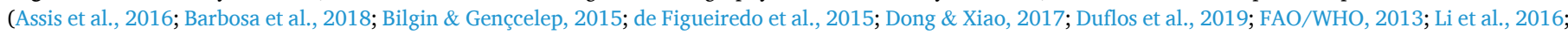
Muscarella et al., 2005; Palermo et al., 2013; Self et al., 2011; Visciano, Schirone, Tofalo, \& Suzzi, 2012).

Table 2

Analytical figures of merit of the USA $\mu$ ET/UHPLC-FLD method for the determination of BAs in tuna fish samples.

\begin{tabular}{|c|c|c|c|c|c|c|c|c|c|c|c|}
\hline \multirow[t]{2}{*}{ BAs } & \multirow{2}{*}{$\begin{array}{l}\mathrm{RT} \\
(\mathrm{min})\end{array}$} & \multirow{2}{*}{$\begin{array}{l}\mathrm{LDR}(\mathrm{mg} \\
\left.\mathrm{kg}^{-1}\right)\end{array}$} & \multirow[t]{2}{*}{ Linear equation } & \multirow[t]{2}{*}{$\mathrm{R}^{2}$} & \multirow{2}{*}{$\begin{array}{l}\text { LOD (mg } \\
\left.\mathrm{kg}^{-1}\right)\end{array}$} & \multirow{2}{*}{$\begin{array}{l}\text { LOQ (mg } \\
\left.\mathrm{kg}^{-1}\right)\end{array}$} & \multirow[t]{2}{*}{ ME (\%) } & \multirow{2}{*}{$\begin{array}{l}\text { Spiked level } \\
\left(\mathrm{mg} \mathrm{kg}^{-1}\right)\end{array}$} & \multirow{2}{*}{$\begin{array}{l}\text { Recovery } \\
(\%)\end{array}$} & \multicolumn{2}{|c|}{ Precision (RSD,\%) } \\
\hline & & & & & & & & & & $\begin{array}{l}\text { Intra-day } \\
(n=5)\end{array}$ & $\begin{array}{l}\text { Inter-day } \\
(\mathrm{n}=15)\end{array}$ \\
\hline Try & 5.81 & $25-750$ & $\begin{array}{l}y= \\
0.0304 x+0.00565\end{array}$ & $\begin{array}{l}0.9990 \pm \\
0.002\end{array}$ & $4.97 \pm 0.5$ & $14.9 \pm 0.3$ & $\begin{array}{l}29.6 \pm \\
0.3\end{array}$ & $\begin{array}{l}25 \\
250 \\
750\end{array}$ & $\begin{array}{l}87 \pm 3 \\
93 \pm 4 \\
99 \pm 2\end{array}$ & $\begin{array}{l}9.8 \\
4.7 \\
6.3\end{array}$ & $\begin{array}{l}10.5 \\
7.1 \\
8.5\end{array}$ \\
\hline Put & 7.14 & $5-750$ & $y=0.0302 x-0.1091$ & $\begin{array}{l}0.9967 \pm \\
0.001\end{array}$ & $0.98 \pm 0.1$ & $3.20 \pm 0.2$ & $\begin{array}{l}32.4 \pm \\
0.5\end{array}$ & $\begin{array}{l}5 \\
250 \\
750\end{array}$ & $\begin{array}{l}76 \pm 1 \\
81 \pm 3 \\
99 \pm 4\end{array}$ & $\begin{array}{l}9.3 \\
6.3 \\
7.9\end{array}$ & $\begin{array}{l}12.9 \\
8.8 \\
8.5\end{array}$ \\
\hline Cad & 8.06 & $25-750$ & $\begin{array}{l}y= \\
0.0487 x+0.4876\end{array}$ & $\begin{array}{l}0.9809 \pm \\
0.003\end{array}$ & $5.24 \pm 0.3$ & $14.9 \pm 0.2$ & $\begin{array}{l}42.6 \pm \\
0.2\end{array}$ & $\begin{array}{l}25 \\
250 \\
750\end{array}$ & $\begin{array}{l}87 \pm 3 \\
93 \pm 1 \\
106 \pm 2\end{array}$ & $\begin{array}{l}6.7 \\
8.3 \\
5.1\end{array}$ & $\begin{array}{l}8.2 \\
10.4 \\
7.4\end{array}$ \\
\hline Spm & 8.95 & $25-750$ & $y=0.0003 x-0.0025$ & $\begin{array}{l}0.9929 \pm \\
0.002\end{array}$ & $7.39 \pm 0.2$ & $22.4 \pm 0.1$ & $\begin{array}{l}2.01 \pm \\
0.6\end{array}$ & $\begin{array}{l}25 \\
250 \\
750\end{array}$ & $\begin{array}{l}79 \pm 3 \\
87 \pm 4 \\
99 \pm 2\end{array}$ & $\begin{array}{l}7.4 \\
8.3 \\
4.4\end{array}$ & $\begin{array}{l}12.8 \\
5.5 \\
6.9\end{array}$ \\
\hline Hist & 9.21 & $25-750$ & $y=0.0023 x-0.0441$ & $\begin{array}{l}0.9887 \pm \\
0.001\end{array}$ & $2.71 \pm 0.1$ & $8.31 \pm 0.2$ & $\begin{array}{l}7.52 \pm \\
0.3\end{array}$ & $\begin{array}{l}25 \\
250 \\
750\end{array}$ & $\begin{array}{l}80 \pm 3 \\
95 \pm 1 \\
103 \pm 3\end{array}$ & $\begin{array}{l}11.6 \\
5.4 \\
9,1\end{array}$ & $\begin{array}{l}14.2 \\
7.9 \\
8.8\end{array}$ \\
\hline Tyrm & 10.84 & $125-750$ & $\begin{array}{l}y= \\
0.0064 x+0.1556\end{array}$ & $\begin{array}{l}0.9877 \pm \\
0.004\end{array}$ & $8.57 \pm 0.2$ & $25.6 \pm 0.3$ & $\begin{array}{l}50.0 \pm \\
0.8\end{array}$ & $\begin{array}{l}125 \\
250 \\
750\end{array}$ & $\begin{array}{l}94 \pm 3 \\
91 \pm 5 \\
103 \pm 1\end{array}$ & $\begin{array}{l}9.1 \\
8.7 \\
7.1\end{array}$ & $\begin{array}{l}9.7 \\
9.2 \\
8.4\end{array}$ \\
\hline Spd & 11.22 & $25-750$ & $y=0.0037 x-0.0456$ & $\begin{array}{l}0.9938 \pm \\
0.002\end{array}$ & $6.59 \pm 0.1$ & $20.1 \pm 0.1$ & $\begin{array}{l}15.3 \pm \\
0.7\end{array}$ & $\begin{array}{l}25 \\
250 \\
750\end{array}$ & $\begin{array}{l}88 \pm 2 \\
79 \pm 3 \\
103 \pm 4\end{array}$ & $\begin{array}{l}7.3 \\
5.8 \\
6,5\end{array}$ & $\begin{array}{l}11.3 \\
9.4 \\
6.9\end{array}$ \\
\hline
\end{tabular}

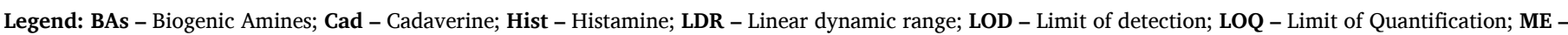

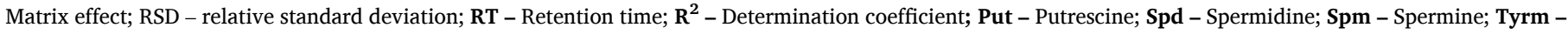
Tyramine; Try - Tryptamine.

the literature using similar chromatographic approaches (Table 1). The recovery (76 $\pm 1 \%-106 \pm 4 \%)$, intra-day (4.4\%-11.6\%) and inter-day precision $(5.5 \%-14.2 \%)$, are also within acceptable analytical ranges (Table 2). However, the matrix effect, which measures the eventual interference of the sample components in the instrument response and consequently in the analysis and quality of the results obtained, ranged from $2.0 \%$ to $50 \%$ (Table 2). This suggests an influence of the sample in the extractive process of some of the dansylated BAs, namely Try, Put, Cad and Tyrm. For this reason, the BAs quantification was performed using the standard addition method. Nevertheless, the proposed methodology presents many advantages in comparison with other techniques previously reported in the literature, as a reduced sample and reagent amounts, a lower derivatization temperature and a much faster and simpler derivatization reaction.

\subsection{The occurrence of BAs in tuna samples}

The validated methodology was applied to different types of tuna fish samples - fresh tuna fish (wm and dm), frozen tuna fish steak containing only wm, and several types of canned tuna fish (pate, oil, olive oil, and natural). Fig. 3B shows the concentration profile of BAs present in the analysed samples. The levels of Cad and Hist are high in wm, while dm is rich in Spd. These results are in agreement with the work of Ruiz-Capillas and Moral (2001) which reported an increase in the concentration of Cad, His, and Tyrm throughout the tuna fish storage and higher concentrations in wm than in $\mathrm{dm}$. The exceptions are Spm and Put which present higher concentrations in $\mathrm{dm}$ than in wm. Put, for instance, has been previously found at high concentration in the $\mathrm{dm}$ upon 5 days storage at low temperatures $\left(1-2{ }^{\circ} \mathrm{C}\right)$ (Bai et al., 2019). This may be the 
cause of the observed discrepancy since the wm and $\mathrm{dm}$ samples were analysed after frozen. The results also showed that Cad is the most abundant BA, being consistently present at high levels in all analysed samples. According to Ruiz-Capillas and Moral (2001), the presence of Cad results from an autolytic process that starts promptly with fish death, being then amplified by microorganisms that start to colonize the fish. But these BAs can occur also in other food matrices. Bunkka et al. (2012), for instance, found levels of Put, Tyrm and Cad, up to $100 \mathrm{mg} / \mathrm{L}$ in beers from the Czech Republic. Novella-Rodríguez, Veciana-Nogués, Roig-Sagués, Trujillo-Mesa, and Vidal-Carou (2004) reported levels of Hist, Tyrm, Put and Cad, in the ripening of goat cheeses from pasteurized and raw milk of $376.6,1585.4,257.2$, and $2101.4 \mathrm{mg} \mathrm{kg}^{-1}$, while Yongsawatdigul, Choi, and Udomporn (2004) found levels of the same BAs of 574.7, 117.3, 308.2, and $685.5 \mathrm{mg} \mathrm{kg}^{-1}$, respectively. Regarding the canned samples, the naturally preserved tuna fish samples presented the highest concentrations of BAs (except for Spm). This may be due to different reasons related to the media in which samples are conserved. The water, oil or olive oil used to process the canned tuna fish samples certainly elicit a different inhibitory effect on microbial development and, consequentially in BAs generation. Furthermore, the affinity for the extraction solvent (ACN), will be different for each of the media used. It would be required a controlled set of tuna fish samples to discriminate the contribution of such effects in the quantification of the dansylated BAs. Overall, at least in what concerns to the current legislation, the tuna fish samples analysed do not represent any risk as the quantified Hist levels fall below the $50 \mathrm{mg} \mathrm{kg} \mathrm{kg}^{-1}$ defined by FDA as safe for human consumption. However, the absence of legislation and conclusive studies regarding the safe levels for other BAs, namely Put and Cad, does not allow us to know whether the amounts we found for these three BAs constitute a risk to human health. We can, however, follow the Quality Index (QI) classification of Mietz and Karmas (1977) to verify the quality of tuna fish samples analysed. The QI was determined for all the samples as previously described in Equation (1), and the results obtained are presented in Table 3. As it can be observed, only the canned tuna fish in olive oil presenting a QI of 0.77 can be considered of good quality. The QI of remaining tuna fish samples ranges between 1 and 4.64, indicating different degrees of deterioration that negatively affect the quality of the respective tuna fish samples. Nevertheless, those samples are still safe for human consumption, at least in what concerns to the presence of BAs.

\section{Conclusions}

Monitoring the occurrence of BAs and other hazardous compounds in foods is of utmost importance to ensure high quality and safety of all dietary products. In this context, a sensitive method using an USA $\mu$ ET approach combined with UHPLC-FLD chromatographic analysis was developed to monitor the occurrence of BAs - Try, Put, Cad, Spm, His, Tyrm and Spd, in different types of commercial tuna fish. The methodology was properly validated exhibiting good analytical performance in the concentration range of $5-750 \mathrm{mg} \mathrm{kg}^{-1}$. The USA $\mu$ ET/UHPLC-FLD methodology was used to analyse several tuna fish samples and a great variation in individual and total BAs was observed. Frozen tuna had the highest levels of BAs, followed by samples of canned tuna and fresh tuna. The results obtained demonstrate that the validated USA $\mu$ ET/UHPLCFLD methodology presents several improvements regarding previous approaches reported in the literature. This includes a simple and fast analytical layout, good sensitivity and robustness, and low sample and reagents requirements.

\section{CRediT authorship contribution statement}

Joanna K.G. Pataca: Formal analysis, Investigation, Data curation, Writing - original draft. Priscilla Porto-Figueira: Formal analysis, Investigation, Writing - review \& editing. Jorge A.M. Pereira: Methodology, Data curation, Writing - review \& editing, Funding acquisition.
Table 3

Quality index (QI) of the tuna fish samples analysed ${ }^{\mathrm{a}}$.

\begin{tabular}{lllll}
\hline Sample & & $\begin{array}{l}\text { Storage } \\
\text { temperature }\end{array}$ & QI & Classification \\
\hline Fresh tuna fish & $\begin{array}{l}\text { Dark muscle } \\
\text { White }\end{array}$ & $4{ }^{\circ} \mathrm{C}$ & 1.44 & Poor quality \\
& $\begin{array}{l}\text { muscle } \\
\text { Frozen tuna fish }\end{array}$ & & 2.31 & Poor quality \\
& White & $-20{ }^{\circ} \mathrm{C}$ & $>10$ & Decomposition \\
Canned tuna & Olive oil & & & \\
fish & & & 0.77 & Good quality \\
& Oil & RT & & \\
& Natural & & 4.65 & Poor quality \\
& Pate & & 2.29 & Poor quality \\
& & & & \\
\hline
\end{tabular}

a Samples description, including time of storage, are detailed in subsection 2.2 of Materials and Methods, $\mathrm{RSD}<5 \%$. QI - quality index, RT - room temperature.

Helena Caldeira: Resources, Writing - review \& editing, Supervision. José S. Câmara: Conceptualization, Methodology, Data curation, Writing - review \& editing, Supervision, Funding acquisition.

\section{Declaration of competing interest}

The authors declare that they have no known competing financial interests or personal relationships that could have appeared to influence the work reported in this paper.

\section{Acknowledgements}

The authors acknowledge FCT-Fundação para a Ciência e a Tecnologia through the CQM Base Fund - UIDB/00674/2020, the Programmatic Fund - UIDP/00674/2020 and the PhD fellowship SFRH/BD/ 129630/2017 granted to Priscilla Porto-Figueira. The authors also acknowledge Madeira 14-20 Program, project PROEQUIPRAM Reforço do Investimento em Equipamentos e Infraestruturas Científicas RAM (M1420-01-0145-FEDER-000008), ARDITI - Agência Regional para o Desenvolvimento da Investigação Tecnologia e Inovação through the project M1420-01-0145-FEDER-000005 - Centro de Química da Madeira - CQM+ (Madeira 14-20 Program) and Project M1420 - 095369-FSE-000001 for the Post-Doctoral fellowship granted to JAMP.

\section{Appendix A. Supplementary data}

Supplementary data to this article can be found online at https://doi. org/10.1016/j.lwt.2020.110804.

\section{References}

Altieri, I., Semeraro, A., Scalise, F., Calderari, I., \& Stacchini, P. (2016). European official control of food: Determination of histamine in fish products by a HPLC-UV-DAD method. Food Chemistry, 211, 694-699. https://doi.org/10.1016/j. foodchem. 2016.05.111

Assis, D. C. S., Menezes, L. D. M., Lima, A. L., Klein, R. W. T., Heneine, L. G. D., Lara, L. J. C., ... Figueiredo, T. C. (2016). Validation of an HPLC-UV method for the identification and quantification of bioactive amines in chicken meat. Arquivo Brasileiro de Medicina Veterinária e Zootecnia, 68, 805-813.

Bai, J., Baker, G. L., Baker, S. M., Goodrich Schneider, R. M., Montazeri, N., \& Sarnoski, P. J. (2019). Simultaneous determination of amino acids and biogenic amines in tuna and Mahi-Mahi by reversed-phase ultra-high performance liquid chromatography. Journal of Aquatic Food Product Technology, 28(8), 848-860. https://doi.org/10.1080/10498850.2019.1652715

Barbosa, R. G., Gonzaga, L. V., Lodetti, E., Olivo, G., Costa, A. C. O., Aubourg, S. P., et al. (2018). Biogenic amines assessment during different stages of the canning process of skipjack tuna (Katsuwonus pelamis). International Journal of Food Science and Technology, 53(5), 1236-1245. https://doi.org/10.1111/ijfs.13703

Bilgin, B., \& Gençcelep, H. (2015). Determination of biogenic amines in fish products. Food Science and Biotechnology, 24(5), 1907-1913. https://doi.org/10.1007/s10068015-0251-4

Buňka, F., Budinský, P., Čechová, M., Drienovský, V., Pachlová, V., Matoulková, D., .. Buňková, L. (2012). Content of biogenic amines and polyamines in beers from the Czech Republic. Journal of the Institute of Brewing, 118(2), 213-216. https://doi.org/ $10.1002 / \mathrm{jib} .31$ 
Commission Regulation (EC). (2002). COMMISSION DECISION of 12 August 2002 implementing Council Directive 96/23/EC concerning the performance of analytical methods and the interpretation of results. https://eur-lex.europa.eu/legal-content /EN/TXT/PDF/?uri=CELEX:32002D0657\&from=EN.

Commission Regulation (EC). (2005). COMMISSION REGULATION (EC) No 2073/2005 on the microbiological criteria for foodstuff. https://eur-lex.europa.eu/legal-content /EN/TXT/PDF/?uri=CELEX:32005R2073\&from=EN.

Dong, H., \& Xiao, K. (2017). Modified QuEChERS combined with ultra high performance liquid chromatography tandem mass spectrometry to determine seven biogenic amines in Chinese traditional condiment soy sauce. Food Chemistry, 229, 502-508. https://doi.org/10.1016/j.foodchem.2017.02.120

Duflos, G., Inglebert, G., Himber, C., Degremont, S., Lombard, B., \& Brisabois, A. (2019). Validation of standard method EN ISO 19343 for the detection and quantification of histamine in fish and fishery products using high-performance liquid chromatography. International Journal of Food Microbiology, 288, 97-101. https:// doi.org/10.1016/j.ijfoodmicro.2018.07.023

Ekici, K., \& Omer, A. K. (2018). The determination of some biogenic amines in Turkish fermented sausages consumed in Van. Toxicology Reports, 5, 639-643.

Esatbeyoglu, T., Ehmer, A., Chaize, D., \& Rimbach, G. (2016). Quantitative determination of spermidine in 50 German cheese samples on a core-shell column by high-performance liquid chromatography with a photodiode array detector using a fully validated method. Journal of Agricultural and Food Chemistry, 64(10), 2105-2111. https://doi.org/10.1021/acs.jafc.6b00078

Evangelista, W. P., Silva, T. M., Guidi, L. R., Tette, P. A. S., Byrro, R. M. D., SantiagoSilva, P., ... Gloria, M. B. A. (2016). Quality assurance of histamine analysis in fresh and canned fish. Food Chemistry, 211.

FAO/WHO. (2013). Public health risks of histamine and other biogenic amines from fish and fishery products: Meeting report. Geneva: World Health Organization.

de Figueiredo, T. C., de Assis, D. C., Menezes, L. D., da Silva, G. R., Lanza, I. P., Heneine, L. G., et al. (2015). HPLC-UV method validation for the identification and quantification of bioactive amines in commercial eggs. Talanta, 142, 240-245. https://doi.org/10.1016/j.talanta.2015.04.056

Latorre-Moratalla, M. L., Bosch-Fusté, J., Lavizzari, T., Bover-Cid, S., VecianaNogués, M. T., \& Vidal-Carou, M. C. (2009). Validation of an ultra high pressure liquid chromatographic method for the determination of biologically active amines in food. Journal of Chromatography A, 1216(45), 7715-7720.

Lee, S., Yoo, M., \& Shin, D. (2015). The identification and quantification of biogenic amines in Korean turbid rice wine, Makgeolli by HPLC with mass spectrometry detection. LWT - Food Science and Technology, 62, 350-356.

Li, Q., Li, D., Qin, N., Hong, H., \& Luo, Y. (2016). Comparative studies of quality changes in white and dark muscles from common carp (Cyprinus carpio) during refrigerated $\left(4{ }^{\circ} \mathrm{C}\right)$ storage. International Journal of Food Science and Technology, 51(5), 1130-1139. https://doi.org/10.1111/ijfs.13090

Liu, S.-J., Xu, J.-J., Ma, C.-L., \& Guo, C.-F. (2018). A comparative analysis of derivatization strategies for the determination of biogenic amines in sausage and cheese by HPLC. Food Chemistry, 266, 275-283.

Loizzo, M. R., Spizzirri, U. G., Bonesi, M., Tundis, R., Picci, N., \& Restuccia, D. (2016). Influence of packaging conditions on biogenic amines and fatty acids evolution during 15 months storage of a typical spreadable salami ('Nduja). Food Chemistry, 213, 115-122.

Mercogliano, R., \& Santonicola, S. (2019). Scombroid fish poisoning: Factors influencing the production of histamine in tuna supply chain. A review. Lwt, 114, 108374. https://doi.org/10.1016/j.lwt.2019.108374

Mietz, J. L., \& Karmas, E. (1977). Chemical quality index of canned tuna as determined by high-pressure liquid chromatography. Journal of Food Science, 42(1), 155-158. https://doi.org/10.1111/j.1365-2621.1977.tb01240.x

Milheiro, J., Ferreira, L. C., Filipe-Ribeiro, L., Cosme, F., \& Nunes, F. M. (2019). A simple dispersive solid phase extraction clean-up/concentration method for selective and sensitive quantification of biogenic amines in wines using benzoyl chloride derivatisation. Food Chemistry, 274, 110-117. https://doi.org/10.1016/j. foodchem.2018.08.116

Muscarella, M., Iammarino, M., Centonze, D., \& Palermo, C. (2005). Measurement of histamine in seafood by HPLC, CE, and ELISA: Comparison of three techniques. Veterinary Research Communications, 29(Suppl 2), 343-346. https://doi.org/ 10.1007/s11259-005-0077-2

Novella-Rodríguez, S., Veciana-Nogués, M. T., Roig-Sagués, A. X., Trujillo-Mesa, A. J., \& Vidal-Carou, M. C. (2004). Evaluation of biogenic amines and microbial counts throughout the ripening of goat cheeses from pasteurized and raw milk. Journal of Dairy Research, 71(2), 245-252. https://doi.org/10.1017/S0022029904000147

Palermo, C., Muscarella, M., Nardiello, D., Iammarino, M., \& Centonze, D. (2013). A multiresidual method based on ion-exchange chromatography with conductivity detection for the determination of biogenic amines in food and beverages. Analytical and Bioanalytical Chemistry, 405(2-3), 1015-1023. https://doi.org/10.1007/s00216012-6439-z

Pereira, J., Porto Figueira, P., Andrade, B., Gonçalves, P., Pataca, J., \& Câmara, J. (2017). Biogenic amines in food: Occurrence and analytical challenges for their analysis.

Perestrelo, R., Petronilho, S., Câmara, J. S., \& Rocha, S. M. (2010). Comprehensive twodimensional gas chromatography with time-of-flight mass spectrometry combined with solid phase microextraction as a powerful tool for quantification of ethyl carbamate in fortified wines. The case study of Madeira wine. Journal of Chromatography A, 1217(20), 3441-3445. https://doi.org/10.1016/j. chroma.2010.03.027

Porto-Figueira, P., Camacho, I., \& Câmara, J. S. (2015). Exploring the potentialities of an improved ultrasound-assisted quick, easy, cheap, effective, rugged, and safe-based extraction technique combined with ultrahigh pressure liquid chromatographyfluorescence detection for determination of Zearalenone in cereals. Journal of Chromatography A, 1408, 187-196. https://doi.org/10.1016/j.chroma.2015.07.031

Ruiz-Capillas, C., \& Moral, A. (2001). Production of biogenic amines and their potential use as quality control indices for hake (Merluccius merluccius, L.) stored in ice. Journal of Food Science, 66(7), 1030-1032. https://doi.org/10.1111/j.13652621.2001.tb08230.x

Santos, C., Roseiro, C., Gonçalves, H., Aleixo, C., Moniz, C., \& da Ponte, D. J. B. (2019). Susceptibility of dry-cured tuna to oxidation and biogenic amines generation related to microbial status and salting/curing technology. Lebensmittel-Wissenschaft \& Technologie, 115, 108420. https://doi.org/10.1016/j.lwt.2019.108420

Self, R. L., Wu, W. H., \& Marks, H. S. (2011). Simultaneous quantification of eight biogenic amine compounds in tuna by matrix solid-phase dispersion followed by HPLC-orbitrap mass spectrometry. Journal of Agricultural and Food Chemistry, 59(11), 5906-5913. https://doi.org/10.1021/jf200455r

Tameem, A. A., Saad, B., Makahleh, A., Salhin, A., \& Saleh, M. I. (2010). A 4-hydroxy-N'[(E)-(2-hydroxyphenyl)methylidene]benzohydrazide-based sorbent material for the extraction-HPLC determination of biogenic amines in food samples. Talanta, 82(4), 1385-1391.

Visciano, P., Schirone, M., Tofalo, R., \& Suzzi, G. (2012). Biogenic amines in raw and processed seafood. Frontiers in Microbiology, 3(188). https://doi.org/10.3389/ fmicb.2012.00188 [Review].

Yongsawatdigul, J., Choi, Y. J., \& Udomporn, S. (2004). Biogenic amines formation in fish sauce prepared from fresh and temperature-abused Indian anchovy (stolephorus indicus). Journal of Food Science, 69(4), FCT312-FCT319. https://doi.org/10.1111/ j.1365-2621.2004.tb06333.x

Yoshida, T., Hamada, H., Murakawa, H., Yoshimoto, H., Tobino, T., \& Toda, K. (2012). Determination of histamine in seafood by hydrophilic interaction chromatography/ tandem mass spectrometry. Analytical Sciences, 28(2), 179.

Đorđević, Đ., Buchtová, H., \& Borkovcová, I. (2016). Estimation of amino acids profile and escolar fish consumption risks due to biogenic amines content fluctuations in vacuum skin packaging/VSP during cold storage. Lebensmittel-Wissenschaft und -Technologie- Food Science and Technology, 66, 657-663. https://doi.org/10.1016/j. lwt.2015.11.020 